\title{
The effect of dietary ionophores on feedlot performance of lambs
}

\author{
M.M. Price, O.B. Einkamerer ${ }^{\#}$, F.H. de Witt, J.P.C. Greyling and M.D. Fair \\ Department of Animal, Wildlife and Grassland Sciences, University of the Free State, P.O. Box 339, Bloemfontein \\ 9300, South Africa
}

\begin{abstract}
This study was conducted to evaluate the effect of different rumen fermentation modifiers (ionophores) in feedlot finisher diets on the production performance of S.A. Mutton Merino lambs. Monensin $(16.4 \mathrm{mg} / \mathrm{kg})$, lasalocid $(33.0 \mathrm{mg} / \mathrm{kg})$ or salinomycin $(17.5 \mathrm{mg} / \mathrm{kg})$ was incorporated into a commercial high-protein (398 g CP/kg DM) concentrate. Treatment diets consisted of maize meal (650 $\mathrm{g} / \mathrm{kg})$, lucerne hay $(150 \mathrm{~g} / \mathrm{kg})$ and a protein concentrate $(200 \mathrm{~g} / \mathrm{kg}$; containing an ionophore or not) to supply isonitrogenous (177 g CP/kg DM) total mixed diets during the experimental period. Sixty lambs (29.7 \pm 2.5 $\mathrm{kg}$ ) were randomly allocated to the treatment groups $(\mathrm{n}=15 /$ treatment $)$ and each treatment was further subdivided into five replicates $(\mathrm{n}=3 /$ replicate). Individual body weight and average feed intake per replicate were recorded weekly and used to calculate the feed conversion ratio (FCR) and average daily gain (ADG). Ionophore treatment had no effect on any of the feedlot performance parameters measured (feed intake: 1379, 1434, 1534 and 1559 g DM/day; ADG: 298, 314, 340 and 329 g/day; FCR: 4.66, 4.58, 4.51 and 4.74 g DM intake/kg live weight gained for the Control, Monensin, Lasalocid and Salinomycin treatments, respectively. The results suggest the efficiency of the different rumen fermentation modifiers to be similar and financial implications and/or animal preference would influence their usage in sheep diets.
\end{abstract}

Keywords: Feed efficiency, ionophores, lambs, production

${ }^{\#}$ Corresponding author. E-mail: einkamererob.sci@ufs.ac.za

\section{Introduction}

Management practices to improve growth performance of ruminants include manipulating feed so that the rate of digestion is not too rapid - which could result in digestive problems, nor too slow - which could result in poor feed efficiency rates (Hatfield et al., 1997). Rumen metabolic modifiers (ionophores) have been shown to have a positive effect on live weight gain, feed conversion ratio and a resultant decrease in carcass fatness. These metabolic modifiers are thus mainly developed to improve the efficiency and profitability of meat production and subsequently to improve carcass composition (Dikeman, 2007). Carboxylic polyether ionophore antibiotics, produced by various strains of Streptomyces spp., are compounds of these rumen metabolic modifiers and include products such as monensin, lasalocid and salinomycin. Bergen \& Bates (1984) and Nagaraja (1995) also reported that the overall effectiveness of these compounds seem to be similar, although they may vary, depending on the dietary inclusion level, diet composition, and various inherent animal factors.

Changes in fermentation, associated with ionophore feeding, have mainly result in an increased production of propionate and decreased production of methane, lactic acid and froth formation in the rumen. A decreased degradation of protein and de-amination of amino acids in the rumen has also been recorded (Bergen \& Bates, 1984). Due to these changes in rumen fermentation, the efficiency of energy and nitrogen metabolism is improved, and the presence of ruminal disorders reduced. Ionophores (especially salinomycin) have also exhibited effectiveness in the treatment of coccidial infections in poultry and cattle (Zinn, 1986).

Even though all ionophores are fermentation products, it is important that they should be viewed as discrete chemical entities with their own distinct properties, rather than as a uniform group with uniform effects, in order to obtain maximum benefits (Wessels, 1993). The subsequent lack of literature regarding the effect of dietary ionophore inclusion on production performances and carcass composition of intensively fed lambs is one shortcoming that needs to be addressed, since it hinders the decision-making processes of producers and feed manufacturers.

The aim of this study was to determine the effect of various ionophores on certain feedlot performance parameters of S.A. Mutton Merino (SAMM) lambs during an intensive feeding period. 


\section{Materials and Methods}

All procedures conducted during this study were approved by the Ethical Control Committee for Animal Experimentation at the University of the Free State (Animal Experiment No. 12/07). Dietary treatments consisted of monensin, lasalocid, salinomycin or a control diet with no ionophore inclusion. The dietary inclusion (as fed) of monensin, lasalocid or salinomycin (16.5, 33.0 and $17.5 \mathrm{mg}$ active ingredient $/ \mathrm{kg}$ diet, respectively) into the high protein concentrate (398 g CP/ $\mathrm{kg} \mathrm{DM}$ ) of each treatment was according to the mean registered (Act 36/1947) levels of the respective suppliers. Each experimental diet consisted of a protein concentrate $(200 \mathrm{~g} / \mathrm{kg})$, lucerne hay $(150 \mathrm{~g} / \mathrm{kg})$ and maize meal $(650 \mathrm{~g} / \mathrm{kg})$ containing on average 177 $\pm 0.6 \mathrm{~g} \mathrm{CP} / \mathrm{kg} \mathrm{DM}, 18.2 \pm 1.8 \mathrm{MJ}$ GE/kg DM, $147 \pm 1.6 \mathrm{~g} \mathrm{NDF} / \mathrm{kg} \mathrm{DM}, 8.4 \pm 0.1 \mathrm{~g} \mathrm{Ca} / \mathrm{kg} \mathrm{DM}, 2.4 \pm 0.02 \mathrm{~g}$ $\mathrm{P} / \mathrm{kg} \mathrm{DM}, 0.4 \pm 0.0 \mathrm{~g} \mathrm{EE} / \mathrm{kg} \mathrm{DM}$ and $67 \pm 0.5 \mathrm{~g}$ ash $/ \mathrm{kg} \mathrm{DM}$. The only difference between the four diets was therefore the ionophore (type) included or not (Control).

Sixty (60) S.A. Mutton Merino (SAMM) lambs were weighed $(29.7 \pm 2.5 \mathrm{~kg})$ and randomly allocated to the four treatments ( $n=15 /$ treatment), each with five replicates. Animals ( $n=3 /$ replicate) were housed in pens $\left(6.5 \mathrm{~m}^{2}\right)$ on slatted floors.

At the onset of the study all animals were implanted with a hormonal growth promoter (Zeraplix; 72 mg zeranol per animal: Reg. no. G3230) and subjected to a standard health and vaccination programme as practiced in the commercial feedlot sector of South Africa. Animals were subjected to a dietary adaptation period of 14 days, after which feed allocation was on an ad libitum basis for the remainder of the experimental period (60 days). Individual body weights and average feed intake per replicate was recorded weekly and used to calculate the feed conversion ratio (FCR) and average daily gain (ADG). At the start and end of the trial all animals were fasted for $10 \mathrm{~h}$ before recording the live body weight ( $48.7 \pm 4.4 \mathrm{~kg}$ ).

Representative samples (treatment diets and feed refused) were collected from each replicate within a treatment and dried in a force draught oven at $100{ }^{\circ} \mathrm{C}$ for at least 16 hours to determine the DM content. After thorough mixing, these samples were ground to pass through a $1 \mathrm{~mm}$ sieve and stored, pending chemical analyses. The composite feed sample from each treatment offered was collected on a daily basis and the feeds refused on a weekly basis. The DM, NDF, EE, Ca, P and gross energy (GE) of samples were determined according to the procedures described by the AOAC (2000). Crude protein was determined using a Leco Nitrogen analyzer (Leco, 2001). A factor of 6.25 was used to convert the nitrogen $(\mathrm{N})$ content of the samples to CP content.

The effect of dietary ionophore inclusion on certain feedlot performance parameters was statistically analyzed using a fully randomized one-way ANOVA design. The PROC ANOVA procedures of the SAS program (SAS, 1999) were used to test for significant differences between treatments.

\section{Results and Discussion}

The effect of dietary ionophore inclusion on DM feed intake and certain feedlot performance parameters of S.A. Mutton Merino lambs is presented in Table 1.

Table 1 The effect of dietary ionophore inclusion on the mean ( \pm s.d.) dry matter feed intake (DMI) and certain feedlot performance parameters of S.A. Mutton Merino lambs

\begin{tabular}{|c|c|c|c|c|c|c|}
\hline \multirow{2}{*}{ Parameter } & \multicolumn{4}{|c|}{ Treatments } & \multicolumn{2}{|c|}{ Significance } \\
\hline & Control & Monensin & Lasalocid & Salinomycin & $\mathrm{P}^{1}$ & CV (\%) \\
\hline DMI (g/sheep/day) & $1379 \pm 84$ & $1434 \pm 84$ & $1534 \pm 149$ & $1559 \pm 115$ & 0.07 & 7.5 \\
\hline Final body weight (kg) & $47.3 \pm 3.7$ & $48.4 \pm 5.2$ & $49.7 \pm 3.8$ & $49.5 \pm 4.8$ & 0.44 & 9.1 \\
\hline ADG (g/day) & $298 \pm 24$ & $314 \pm 29$ & $340 \pm 35$ & $329 \pm 17$ & 0.11 & 8.4 \\
\hline $\mathrm{FCR}^{2}$ & $4.66 \pm 0.44$ & $4.58 \pm 0.26$ & $4.51 \pm 0.28$ & $4.74 \pm 0.22$ & 0.68 & 6.7 \\
\hline
\end{tabular}

${ }^{1}$ Means tested for significance at $\mathrm{P}=0.05$.

${ }^{2}$ feed conversion ratio $=\mathrm{kg}$ DM feed intake/kg live body weight gained.

No differences $(\mathrm{P}>0.05)$ were recorded regarding $\mathrm{DM}$ feed intake, live weight gain and feed efficiency between the treatments tested (Table 1). These findings in the present study are contradictory with 
the results of Funk et al. (1986). They found that lasalocid improved feed efficiency $(\mathrm{P}<0.10)$ of feedlot lambs. According to Zinn (1986) salinomycin seems not to influence rate of gain, though feed conversion was improved ( $\mathrm{P}<0.05$ ) by an average of $5 \%$ at the 11 to $22 \mathrm{mg} / \mathrm{kg}$ levels of supplementation. Wessels (1993) found that even though salinomycin and monensin improved feed efficiency of cattle to apparently the same extent, these ionophores differ in their effect on ADG and DM feed intake. According to Goodrich et al. (1984) and Merchen \& Berger (1985), feed consumption in cattle fed a monensin or salinomycin treatment decreased while an improvement $(\mathrm{P}<0.05)$ in feed efficiency was recorded. The same effects were observed by Van Vuuren \& Nel (1983) with a monensin treatment. Factors that could have affected the variable animal responses to dietary ionophores include the diet cation concentration, microbial adaptation and diet energy density (Zinn et al., 1994).

Supportive to the findings of the present study, Bergen \& Bates (1984), Funk et al. (1986) and Nagaraja (1995) reported the overall effectiveness of ionophores to be similar, although the agents may vary depending on dietary inclusion level, diet composition and various inherent animal factors. Also, no effect was recorded regarding ADG, DM intake and feed efficiency of steers fed a monensin containing diet (Zinn \& Borques, 1992).

As the different ionophores had no effect $(\mathrm{P}>0.05)$ on any of the tested parameters, it is of special interest to note the effect of the Control diet (no ionophore inclusion) on the production performances of the lambs. Although the DM intake and ADG of the Control group was lowest, it did not differ significantly from the ionophore treatments. This lack of response in the dietary ionophores supplementation, compared to the Control diet, could suggest that the mean registered inclusion levels of the respective ionophores (Act 36/1947) was not adequate to provide a production response. Therefore, the need remains for more research to determine the effect of various ionophore levels on production performance of sheep under feedlot conditions.

\section{Conclusions}

Dietary treatment with ionophores in feedlot finisher diets for lambs had no effect on any of the feedlot performance parameters (DMI, ADG and FCR) tested. These results suggest that the overall effect of type of ionophore on DM feed intake, live weight gain and feed efficiency is negligible. These results are important considering that there is a paucity of research concerning the effect of type of ionophore as a dietary supplement on sheep production performance. More research is warranted in this regard.

\section{References}

AOAC, 2000. Official methods of analysis of AOAC international. Volume 1. 17 ${ }^{\text {th }}$ ed. Ed. Horwitz, W., AOAC International ${ }^{\circledR}$.

Bergen, W.G. \& Bates, D.B., 1984. Ionophores: Their effect on production efficiency and mode of action. J. Anim. Sci. 58, 1465-1483.

Dikeman, M.E., 2007. Effects of metabolic modifiers on carcass traits and meat quality. Meat Sci. 77, 121-135.

Funk, M.A., Galyean, M.L. \& Ross, T.T., 1986. Potassium and lasalocid effects on performance and digestion in lambs. J. Anim. Sci. 63, 685-691.

Goodrich, R.D., Garrett, J.E., Gast, D.R., Kirick, M.A., Larson, D.A. \& Meiske, J.C., 1984. Influence of monensin on the performance of cattle. J. Anim. Sci. 58, 1484-1498.

Hatfield, P.G., Hopkins, J.A., Pritchard, G.T. \& Hunt, C.W., 1997. The effects of amount of whole barley, barley bulk density, and form of roughage on feedlot lamb performance, carcass characteristics, and digesta kinetics. J. Anim. Sci. 75, 3353-3366.

Leco, 2001. FP-528 Protein/Nitrogen Determinator. FP-528 Instruction Manual, Version 1.2. Leco® Corporation.

Merchen, N.R. \& Berger, L.L., 1985. Effect of salinomycin level on nutrient digestibility and ruminal characteristics of sheep and feedlot performance of cattle. J. Anim. Sci. 60, 1338-1346.

Nagaraja, T.J., 1995. Biotechnology in Animal Feeds and Animal Feeding. VCH Publishers Inc., N.Y., USA. SAS, 1999. SAS ${ }^{\circledR}$ User's Guide. Version 6.12. SAS Institute Inc., Cary, N.C., USA.

Van Vuuren, B.G.J. \& Nel, J.W., 1983. Die invloed van Monensin op die doeltreffenheid van voeromset, karkaseienskappe en die voorkoms van koksidiose by lammers. S. Afr. J. Anim. Sci. 13, 87-90. 
Wessels, R.H., 1993. Effect of Salinomycin and Monensin on growth and rumen function. M.Sc. Agric. Production Physiology. University of Pretoria, South Africa.

Zinn, R.A., 1986. Effect of Salinomycin supplementation on carcass characteristics of digestion and feedlot performance of cattle. J. Anim. Sci. 63, 1996-2004.

Zinn, R.A. \& Borques, J.L., 1992. Influence of sodium bicarbonate and Monensin on utilization of a fatsupplemented, high-energy growing-finishing diet by feedlot steers. J. Anim. Sci. 71, 18-25.

Zinn, R.A., Plascencia, A. \& Barajas, R., 1994. Interaction of forage level and Monensin in diets for feedlot cattle on growth performance and digestive function. J. Anim. Sci. 72, 2209-2215. 